\section{Incidental mild hyperglycemia in children: two MODY 2 families identified in Brazilian subjects}

\author{
Hiperglicemia incidental em crianças: duas famílias \\ com MODY 2 identificadas em brasileiros
}

Lílian A. Caetano',2, Alexander A. L. Jorge', Alexsandra C. Malaquias', Ericka B. Trarbach', Márcia S. Queiroz², Márcia Nery², Milena G. Teles ${ }^{1,2}$

\section{SUMMARY}

Maturity-onset diabetes of the young (MODY) is characterized by an autosomal dominant mode of inheritance, early onset of hyperglycemia, and defects of insulin secretion. MODY subtypes described present genetic, metabolic, and clinical differences. MODY 2 is characterized by mild asymptomatic fasting hyperglycemia, and rarely requires pharmacological treatment. Hence, precise diagnosis of MODY is important for determining management and prognosis. We report two heterozygous GCK mutations identified during the investigation of short stature. Case 1: a prepubertal 14-year-old boy was evaluated for constitutional delay of growth and puberty. During follow-up, he showed abnormal fasting glucose (113 mg/dL), increased level of $\mathrm{HbA} 1 \mathrm{c}(6.6 \%)$, and negative $\beta$-cell antibodies. His father and two siblings also had slightly elevated blood glucose levels. The mother had normal glycemia. A GCK heterozygous missense mutation, p.Arg191Trp, was identified in the proband. Eighteen family members were screened for this mutation, and 11 had the mutation in heterozygous state. Case 2: a 4-year-old boy investigated for short stature revealed no other laboratorial alterations than elevated glycemia $(118 \mathrm{mg} / \mathrm{dL}) ; \beta$-cell antibodies were negative. His father, a paternal aunt, and the paternal grandmother also had slightly elevated glycemia, whereas his mother had normal glycemia. A GCK heterozygous missense mutation, p.Glu221Lys, was identified in the index patient and in four family members. All affected patients had mild elevated glycemia. Individuals with normal glycemia did not harbor mutations. GCK mutation screening should be considered in patients with chronic mild early-onset hyperglycemia, family history of impaired glycemia, and negative $\beta$-cell antibodies. Arq Bras Endocrinol Metab. 2012;56(8):519-24

\section{SUMÁRIO}

O diabetes do tipo MODY (maturity-onset diabetes of the young) caracteriza-se por herança autossômica dominante, início precoce da hiperglicemia e defeitos na secreção de insulina. Os subtipos de MODY apresentam diferenças genéticas, metabólicas e clínicas. O MODY 2 é caracterizado por hiperglicemia leve assintomática e raramente requer tratamento farmacológico. 0 diagnóstico preciso de MODY é importante para se determinar o tratamento e o prognóstico. Relatamos duas mutações no gene GCK em heterozigose identificadas durante investigação de baixa estatura. Caso 1: paciente do sexo masculino, com 14 anos, pré-púbere, avaliado por atraso constitucional do crescimento e da puberdade. Durante o acompanhamento, apresentou glicemia de jejum alterada (113 mg/dL), aumento de HbA1c $(6,6 \%)$ e anticorpos anticélulas $\beta$ negativos. Seu pai e dois irmãos também apresentavam glicemia levemente elevada. A mãe tinha glicemia normal. Foi identificada no gene GCK uma mutação missense em heterozigose, p.Arg191Trp. Dezoito membros da família foram rastreados e 11 apresentavam essa mutação. Caso 2: paciente do sexo masculino, com 4 anos, em avaliação por baixa estatura. Não apresentou alterações laboratoriais, exceto por glicemia elevada ( $118 \mathrm{mg} / \mathrm{dL}$ ). Anticorpos anticélulas $\beta$ foram negativos. Seu pai, uma tia paterna e a avó paterna também apresentavam glicemia discretamente elevada, e a mãe, glicemia normal. A mutação missense em heterozigose, p.Glu221 Lys, foi identificada no paciente-índice e em 4 membros da família. Todos os pacientes afetados apresentavam hiperglicemia leve. Essas mutações não foram identificadas nos indivíduos com glicemia normal. O rastreamento de mutações no gene GCK deve ser considerado em pacientes com hiperglicemia crônica leve e de início precoce, história familiar de glicemia elevada e anticorpos anticélulas $\beta$ negativos. Arq Bras Endocrinol Metab. 2012;56(8):519-24
1 Unidade de Endocrinologia Genética e Laboratório de Endocrinologia Molecular e Celular/LIM25, Disciplina de Endocrinologia, Faculdade de Medicina da Universidade de São Paulo (FMUSP), São Paulo, SP, Brazil 2 Unidade de Diabetes, Hospital das Clínicas, FMUSP, São Paulo, SP, Brazil

Correspondence to: Milena G. Teles

Unidade de Endocrinologia Genética, LIM/25, Faculdade de Medicina da Universidade de São Paulo

Av. Dr. Arnaldo, 455, 5o andar, sala 5340 01246-903 - São Paulo, SP, Brazil milena.teles@usp.br

Received on Aug/3/2012 Accepted on Sept/19/2012 


\section{INTRODUCTION}

enetic defects affecting only one gene correspond $\mathbf{I}_{\text {to }} 1 \%$ to $5 \%$ of all cases of diabetes mellitus (DM) $(1,2)$. Different genes related to monogenic diabetes have been identified and are associated with maturityonset diabetes of the young (MODY), neonatal diabetes, mitochondrial diabetes, mutations in the insulin receptor (insulin resistance syndromes), and other genetic syndromes associated to diabetes (e.g. Wolfram syndrome) (3). A number of cases of monogenic diabetes are erroneously classified as type 1 or type 2 diabetes $(4,5)$. It is estimated that close to $5 \%$ of the individuals classified as having type $2 \mathrm{DM}$, and about $10 \%$ of those considered type $1 \mathrm{DM}$, are actual carriers of a MODY mutation (6).

MODY is the most common form of monogenic diabetes, also known as familial diabetes (7). It is characterized by autosomal dominant mode of inheritance, early onset of hyperglycemia (usually before 25 years old) $(2,8)$, defects of insulin secretion (3), and generally lack of beta-cell specific antibodies $(2,8)$. Mutations occurring in MODY genes lead to a profound phenotypic impact (high penetrance), and $95 \%$ of the individual carriers of a MODY mutation will be diabetic or will have altered glycemic metabolism before the age of 55 (6). To date, there are eleven types of MODY described, distinguished by genetic, metabolic, and clinical heterogeneity. Mutations in the genes HNF4A, GCK, HNFIA, PDX1, HNF1B, NEURODI, KLF11, CEL, PAX4, INS, $B L K$ are associated with MODY 1 to 11 , respectively (4). The prevalence of MODY varies among different countries and the most common forms are type 2 and 3 (4). The largest series described so far are in France and England (6). MODY 2 is the most frequent form in France and may account for 50 to $60 \%$ of cases $(9,10)$. MODY 3 is the most prevalent type in British families, accounting for 52 to $63 \%$ of cases $(5,11)$. Differences in the prevalence of MODY 2 and MODY 3 are likely associated with the different ways of ascertainment (evaluation in pediatric or adult clinics, self-reported diabetes, new diagnosis of hyperglycemia through a familial survey; recruitment from outpatient clinics) (8). The prevalence of the different types of MODY in Brazil was evaluated in a total of 48 probands in 3 studies. Among identified mutations, MODY 3 was the most common type, followed by MODY 2 (only few reported variants). MODY 2 and 3 mutations did not explain the majority of MODY cases in the Brazilian population, which resulted in a high prevalence of MODY X (no known mutation), ranging from 46.2 to $73.9 \%$ of the suspected cases (12-14).

MODY 2 is associated with heterozygous inactivating mutations in the gene $G C K$, which is located on chromosome 7 (7pl5.3-pl5.1) and consists of 12 exons (15). The first mutation was reported in 1992 (16), and over 600 different GCK mutations distributed throughout the 10 coding exons have been identified so far. There are no mutation hotspots (17). The GCK gene encodes the 465-amino-acid protein, called glucokinase, which is one of four enzymes of the hexokinase family. It catalyzes the phosphorylation of glucose to produce glucose-6-phosphate as the first step of glycolysis (18). Glucokinase plays an important regulatory role in glucose metabolism. As a glucose sensor, it regulates insulin secretion in pancreatic $\beta$-cells by changing the glucose phosphorylation rate over a range of physiological glucose concentrations (18).

MODY 2 is characterized by a deficiency in glucokinase, and shows a characteristic mild, often asymptomatic, fasting hyperglycemia (19). Most patients have impaired fasting glucose or impaired glucose tolerance, and less than $50 \%$ of affected individuals have overt diabetes $(9,20)$. Diagnosis is usually incidental during childhood, youth, or pregnancy (21). An study on incidental hyperglycemia in patients under 18 years old estimated that approximately $15 \%$ of cases are caused by GCK mutations (22). MODY 2 patients show a small increment in the 2 -hour glucose value observed in the oral glucose tolerance test, which usually is less than $60 \mathrm{mg} / \mathrm{dL}$ (23). In most cases of MODY 2, patients require no pharmacological treatment, and are managed on diet alone. Those patients commonly have no diabetes-related complications $(8,24)$. Hence, precise recognition of this disorder is very important for treatment decisions, and has relevant prognostic value (25). Accurate diagnosis can only be made by molecular genetic testing $(24,26)$.

We report two heterozygous GCK mutations identified during investigation of short stature in two young boys with persistent mild hyperglycemia. These two substitutions have never been reported in the Brazilian population. 


\section{CASE REPORTS}

\section{Case 1}

A prepubertal 14-year-old boy with height of $130 \mathrm{~cm}$ (-3.5 SD) and weight of $25.5 \mathrm{~kg}$ was evaluated for constitutional delay of growth and puberty. During followup, he started puberty at the age of 16, and his adult height was $161 \mathrm{~cm}$. Laboratory evaluation showed impaired fasting glucose $[113-124 \mathrm{mg} / \mathrm{dL}(6.3-6.9$ $\mathrm{mmol} / \mathrm{L})]$, and increased AlC levels $(5.9 \%-6.6 \%)$. Serum anti-GAD, anti-IA2, anti-IAA were negative. Oral glucose tolerance test showed an increase of 35 $\mathrm{mg} / \mathrm{dL}$ in glucose level after $2 \mathrm{~h}$ (Table $\mathrm{l})$. His father also had slightly elevated blood glucose levels, as well as two siblings. A total of eighteen family members were screened. Eleven of them had impaired fasting glucose levels. Follow-up evaluations of this patient and some family members (who were enrolled in our outpatient clinic) were conducted over more than a decade after the initial appointment, and revealed that glycemia have not changed considerably. In addition, screening for retinopathy and nephropathy were negative (Table l).

\section{Case 2}

A 4-year-old boy with $95 \mathrm{~cm}(-1.5 \mathrm{SD})$ and $15.8 \mathrm{~kg}$. During follow-up (3 years), he remained in the fifth percentile in the growth chart, and laboratory tests revealed no alterations other than mild hyperglycemia $[118-123 \mathrm{mg} / \mathrm{dL}(6.6-6.8 \mathrm{mmol} / \mathrm{L})]$. $\beta$-cell antibodies were negative (Table 1 ). His father, a paternal aunt, a paternal cousin, and the paternal grandmother also had slightly elevated glycemia, whereas his mother had normal glycemia. The proband and these four family members with impaired fasting glucose were recruited for genetic evaluation. Follow-up of this patient and his father is shown in table 1 , emphasizing glycemia stability.

Table 1. Clinical and laboratory characterization of patients with MODY 2

\begin{tabular}{|c|c|c|c|c|c|c|}
\hline & \multicolumn{4}{|c|}{ Family 1} & \multicolumn{2}{|c|}{ Family 2} \\
\hline & Proband & Father & Sister & Cousin & Proband & Father \\
\hline GCK mutation & \multicolumn{4}{|c|}{ p.R191W } & \multicolumn{2}{|c|}{ p.E221K } \\
\hline Gender & Male & Male & Female & Female & Male & Male \\
\hline Birth weight $(\mathrm{g})$ & 2450 & NA & NA & NA & 2775 & NA \\
\hline \multicolumn{7}{|l|}{ At diagnosis } \\
\hline Age (years) & 14 & 42 & 14 & 8 & 4 & 35 \\
\hline $\mathrm{BMl}\left(\mathrm{kg} / \mathrm{m}^{2}\right)$ & $15.1^{\mathrm{A}}$ & 17.5 & $25.7^{B}$ & $15.0^{C}$ & $17.5^{\mathrm{B}}$ & 25.8 \\
\hline Fasting glucose level (mg/dL) & 113 & 126 & 112 & 128 & 118 & 128 \\
\hline Fasting insulin level $(\mu \mathrm{U} / \mathrm{mL})$ & 2.9 & 4.9 & 5.3 & 8.6 & 2.0 & 9.0 \\
\hline Fasting C-peptide level $(\mathrm{ng} / \mathrm{mL})^{\mathrm{D}}$ & 1.7 & 1.0 & 1.1 & 0.9 & 2.08 & 2.3 \\
\hline OGTT: basal glucose level (mg/dL) & 120 & 141 & NA & 137 & NA & 134 \\
\hline OGT: 2-hour postload glucose level (mg/dL) & 155 & 146 & NA & 203 & NA & 181 \\
\hline$\beta$-cell antibodies & Negative & Negative & NA & Negative & Negative & Negative \\
\hline \multicolumn{7}{|l|}{ Follow-up } \\
\hline Duration of follow-up (years) & 15 & 12 & 12 & 11 & 3 & 3 \\
\hline Range of fasting glucose levels (mg/dL) & $113-124$ & $119-147$ & $104-140$ & $97-129$ & $118-123$ & $120-134$ \\
\hline Range of fasting insulin levels $(\mu \mathrm{U} / \mathrm{mL})$ & $2.9-4.6$ & $2.5-4.2$ & $5.3-16.9$ & NA & $2.0-4.0$ & NA \\
\hline Range of fasting C-peptide levels (ng/mL) & $0.9-1.3^{\mathrm{D}} ; 1.7^{\mathrm{F}}$ & $1.0^{\mathrm{D}} ; 1.2^{\mathrm{F}}$ & $1.9-2.9^{F}$ & NA & NA & NA \\
\hline Range of $\mathrm{A} 1 \mathrm{C}$ levels (\%) & $5.9-6.6$ & $6.5-7.4$ & $5.5-6.8$ & $5.9-6.6$ & NA & $7.0-7.6$ \\
\hline Microalbuminuria & Negative & Negative & NA & Negative & NA & Negative \\
\hline
\end{tabular}

BMI: body mass index; OGTT: oral glucose tolerance test; NA: not available.

$\beta$-cell antibodies: glutamic acid decarboxylase (GAD) antibody; tyrosine phosphatase antibody (IA2); insulin antibody (IAA).

BMI Percentile for age and sex: ${ }^{A}$ less than the $5^{\text {th }}$ percentile, ${ }^{\mathrm{B}}$ between the $85^{\text {th }}$ and the $95^{\text {th }}$ percentile, ${ }^{\mathrm{C}}$ between the $5^{\text {th }}$ and the $50^{\text {th }}$ percentile,

Laboratory normal range (NR): fasting glucose: NR $70-99 \mathrm{mg} / \mathrm{dL}$; fasting insulin: $\mathrm{NR}<25 \mu \mathrm{U} / \mathrm{mL} ; 2$-hour postload glucose: $\mathrm{NR}<140 \mathrm{mg} / \mathrm{dL}$;

${ }^{D}$ Fasting C-peptide by immunofluorometric assay (NR $0.4-3.6 \mathrm{ng} / \mathrm{mL}$ ); ${ }^{\mathrm{E}} \mathrm{A} 1 \mathrm{C}$ by boronate affinity chromatography, and ion-capture assay (NR $5.5-8.5 \%$ ); ${ }^{\mathrm{F}}$ Fasting C-peptide by immunochemiluminometric assay (NR $1.1-4.4 \mathrm{ng} / \mathrm{mL}) ;{ }^{G} \mathrm{~A} 1 \mathrm{C}$ by high performance liquid chromatography - HPLC (NR $\left.4.1-6 \%\right)$. 


\section{SUBJECTS AND METHODS}

Patients were selected from the Endocrinology Division Outpatient Clinic of Sao Paulo Clinical Hospital, Sao Paulo Medical School, Universidade de São Paulo (USP), Brazil.

Laboratory tests were carried out by standard methodology in the clinical laboratory of the hospital. Plasma glucose (fasting and 2-hour postload) was performed using automated colorimetric enzymatic method (fasting plasma glucose: normal range $70-$ $99 \mathrm{mg} / \mathrm{dL}$; 2-hour postload glucose level: normal range $<140 \mathrm{mg} / \mathrm{dL})$. HbAlC was initially measured by boronate affinity chromatography, and ion-capture assay (normal range $5.5 \%-8.5 \%$ ); and by high performance liquid chromatography - HPLC (normal range $4.1 \%$ - 6\%) since 2006; this method is certified by the National Glycohemoglobin Standardization Program - NGSP. Insulin was measured by immunofluorometric assay (fasting normal range < $25 \mu \mathrm{U} / \mathrm{mL}$ ). Fasting serum C-peptide was measured initially by immunofluorometric assay (normal range $0.4-3.6 \mathrm{ng} / \mathrm{mL}$ ), and more recently, by electrochemiluminescence (normal range $1.1-4.4 \mathrm{ng} / \mathrm{mL}$ ). $\beta$-cell antibodies were evaluated by radioimmunoassay: glutamic acid decarboxylase (GAD) antibody (normal range $<25 \mathrm{U} / \mathrm{mL}$ ); tyrosine phosphatase (IA2) antibody (normal range $<125 \mathrm{U} / \mathrm{mL}$ ); insulin (IAA) antibody (normal range $<0.4 \mathrm{U} / \mathrm{mL}$ ).

Diabetes-related microvascular complications were screened: nephropathy was evaluated by microalbuminuria, which was measured by immunonephelometric assay, and retinopathy was assessed by fundoscopic examination through a dilated pupil.

Genomic DNA was extracted from peripheralblood leukocytes, and the entire coding regions, as well as the exon-intron boundaries of the GCK gene were amplified by polymerase chain reaction (PCR). Genotyping was performed using automated sequencing.

The present study was approved by the Ethics Committee of the hospital. Informed consent was obtained from the patients or their parents.

\section{RESULTS}

Molecular GCK sequence analysis of the first index patient revealed a heterozygous missense mutation CGG>TGG in exon 5 , nucleotide position 571
(c.571C $>\mathrm{T})$, causing a change of the amino acid arginine to tryptophan (p.Arg191Trp) (Figure 1). The father also harbors this mutation, but not the mother, who does not have hyperglycemia. A total of 18 family members were screened for p.Arg 191Trp mutation, and 11 had the mutation in heterozygous state. All affected patients had mild elevated glycemia, and family members with normal glycemia did not harbor the mutation (Figure 2).

GCK sequencing of the second proband identified a heterozygous missense mutation GAG $>$ AAG in exon 6, nucleotide position 661 (c.661G>A), changing the amino acid glutamic acid to lysine (p.Glu221Lys) (Figure 1). Molecular analysis of all family members with hyperglycemia revealed the same mutation (Figure 2).

\section{Chromosome 7p15.3-p15.1}

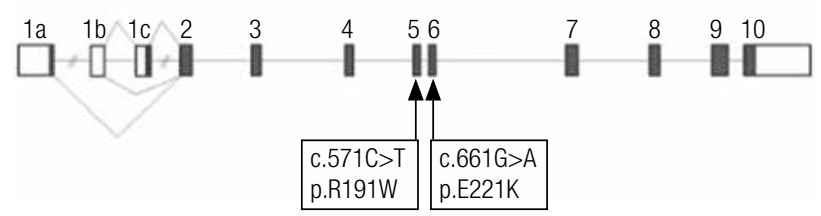

Figure 1. Schematic representation of exons 1 to 10 of glucokinase gene, located in the short arm of chromosome 7. Arrows indicate the mutations identified in this study (first report in Brazilian families).

\section{A}
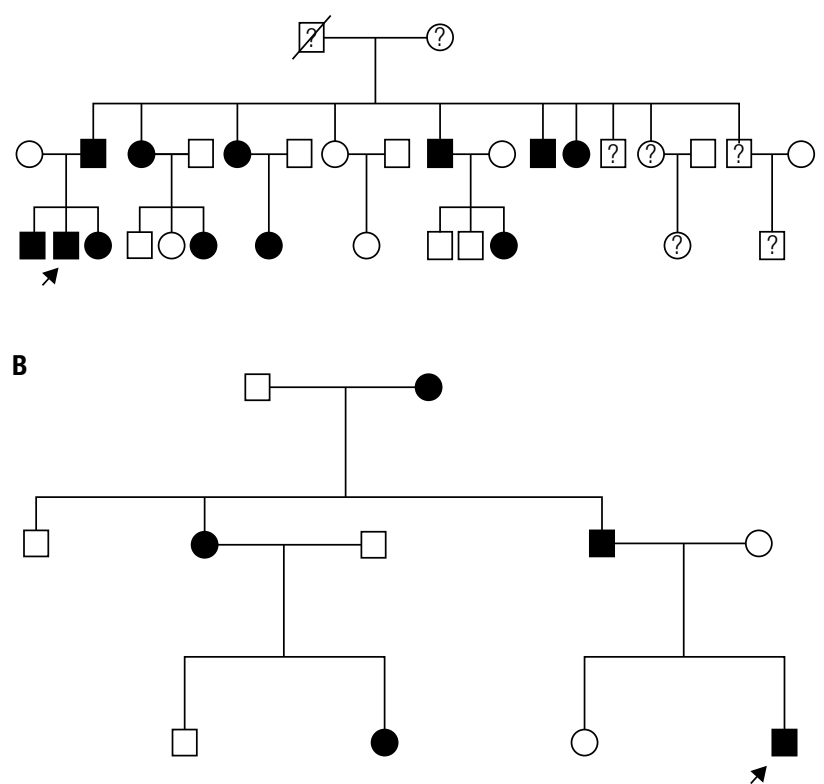

Figure 2. (A) Pedigree of Family 1. (B) Pedigree of Family 2. Arrows identify the probands. Squares denote male family members, and circles denote females. Question marks (?) denote family members with unknown glycemic status, and that were not genotyped. Individuals shown in white had normal glycemia and did not harbor the mutation (wild type GCK), and those shown in black had hyperglycemia and the GCK mutation (MODY 2). 


\section{DISCUSSION}

The two cases reported, which were initially assessed for short stature, had a MODY 2 diagnosis, suspected by persistent mild hyperglycemia and vertical inheritance for at least two consecutive generations. The condition was confirmed by molecular genetic testing. All family members with hyperglycemia also had the GCK mutation.

The variants of GCK gene identified in our study did not segregate with short stature, but with hyperglycemia. Though in our cases short stature was the subject of the initial evaluation, there is no description of association of this disorder of growth with MODY in the literature. Therefore, hyperglycemia in these cases may be regarded as an incidental finding.

Although the functional effects of these two mutations on GCK enzymatic activity have not been directly studied, the p.Arg191Trp mutation have been identified in French, Japanese, Norwegian, and Korean patients with the MODY2 phenotype (20,27-29). p.Glu221Lys mutation was associated with MODY 2 in Italian subjects (30). Even though they have already been reported in other ethnicities, these GCK mutations have never been identified in Brazilian families (12-14).

The first GCK gene mutations found in Brazilian individuals (two novel mutations) were reported in a collaborative study that also included French families (9). In publications including only Brazilian families, a total of five $G C K$ variants have been previously described (12-14): two were novel mutations (14), one was a glucokinase polymorphism (intronic variant that did not co-segregate with diabetes) (12), and another variant that could not be ascertained as a causal mutation (it was not present in a family member with diabetes) (13). This data could not cover all GCK mutations found in Brazilian subjects, as some may have not been published yet, or may be only available in annals of scientific meetings. The prevalence of MODY 2 cases in the Brazilian population is not high, although this might be related to patient age at screening, and availability of molecular genetic tests.

Our study draws attention to the importance of the identification of GCK mutations in patients with mild asymptomatic hyperglycemia in the pediatric setting. This approach has crucial implications for the clinical course, patient management, and family screening. Hence, GCK mutation screening should be considered in patients with chronic asymptomatic hyperglycemia, early age of onset, family history of impaired glycemia, and negative $\beta$-cell antibodies, as we observed in the patients described here.

Acknowledgments: this study was supported by grants from Conselho Nacional de Desenvolvimento Científico e Tecnológico (CNPq) (301477/2009-4 to A.A.L.J) and Universidade de São Paulo (Programa de Apoio aos Novos Docentes 2010.1.37155.1.8).

Disclosure: no potential conflict of interest relevant to this article was reported.

\section{REFERENCES}

1. Centers for Disease Control and Prevention (CDC). Diabetes Public Health Resource. 2011 National Diabetes Fact Sheet [Internet]. 2011. Available from: http://www.cdc.gov/diabetes/pubs/ factsheet11.htm

2. Fajans SS, Bell GI, Polonsky KS. Molecular mechanisms and clinical pathophysiology of maturity-onset diabetes of the young. $\mathrm{N}$ Engl J Med. 2001;345(13):971-80.

3. Reis AF, Velho G. Bases genéticas do diabetes mellitus tipo 2. Arq Bras Endocrinol Metabol. 2002;46(4):426-32.

4. Fajans SS, Bell GI. MODY: history, genetics, pathophysiology, and clinical decision making. Diabetes Care. 2011;34(8):1878-84.

5. Shields BM, Hicks S, Shepherd MH, Colclough K, Hattersley AT, Ellard S. Maturity-onset diabetes of the young (MODY): how many cases are we missing? Diabetologia. 2010;53(12):2504-8.

6. Oliveira CSV, Furuzawa GK, Reis AF. Diabetes mellitus do tipo MODY. Arq Bras Endocrinol Metabol. 2002;46(2):186-92.

7. Hattersley AT, Bruining J, Shield J, Njolstad P, Donaghue KC. ISPAD Consensus - The diagnosis and management of monogenic diabetes in children and adolescents. Pediatr Diabetes. 2009;10(Suppl12):33-42.

8. Vaxillaire M, Froguel P. Monogenic diabetes in the young, pharmacogenetics and relevance to multifactorial forms of type 2 diabetes. Endocr Rev. 2008;29(3):254-64.

9. Velho $G$, Blanché $H$, Vaxillaire $M$, Bellanné-Chantelot $C$, Pardini VC, Timsit J, et al. Identification of 14 new glucokinase mutations and description of the clinical profile of 42 MODY-2 families. Diabetologia. 1997;40(2):217-24.

10. Chèvre $J C$, Hani EH, Boutin $P$, Vaxillaire $M$, Blanché $H$, Vionnet $N$, et al. Mutation screening in 18 Caucasian families suggest the existence of other MODY genes. Diabetologia. 1998;41(9):1017-23.

11. Frayling TM, Evans JC, Bulman MP, Pearson E, Allen L, Owen $K$, et al. Beta-cell genes and diabetes - Molecular and clinical characterization of mutations in transcription factors. Diabetes. 2001;50(Suppl1):S94-100.

12. Moises RS, Reis AF, Morel V, Chacra AR, Dib SA, Bellanné-Chantelot $C$, et al. Prevalence of maturity-onset diabetes of the young mutations in Brazilian families with autosomal- dominant earlyonset type 2 diabetes. Diabetes Care. 2001;24(4):786-8.

13. Maraschin JF, Kannengiesser C, Murussi N, Campagnolo N, Canani $\mathrm{LH}, \mathrm{Gross} \mathrm{JL}$, et al. HNF1 $\alpha$ mutations are present in half of clinically defined MODY patients in South-Brazilian individuals. Arq Bras Endocrinol Metabol. 2008;52(8):1326-31.

14. Furuzawa GK, Giuffrida FMA, Oliveira CSV, Chacra AR, Dib SA, Reis AF. Low prevalence of MODY2 and MODY3 mutations in Brazilian individuals with clinical MODY phenotype. Diabetes Res Clin Pract. 2008;81(3):e12-4. 
15. Stoffel M, Froguel P, Takeda J, Zouali H, Vionnet N, Nishi S, et al. Human glucokinase gene: isolation, characterization, and identification of two missense mutations linked to early-onset noninsulin-dependent (type 2) diabetes mellitus. Proc Natl Acad Sci USA. 1992;89:7698-702.

16. Froguel $P$, Vaxillaire $M$, Sun F, Velho $G$, Zouali $H$, Butel MO, et al. Close linkage of glucokinase locus on chromosome $7 p$ to early-onset non-insulin-dependent diabetes mellitus. Nature. 1992;356(6365):162-4.

17. Osbak KK, Colclough K, Saint-Martin C, Beer NL, Bellanné-Chantelot C, Ellard S, et al. Update on mutations in glucokinase (GCK), which cause maturity-onset diabetes of the young, permanent neonatal diabetes, and hyperinsulinemic hypoglycemia. Hum Mutat. 2009;30(11):1512-26.

18. Matschinsky FM. Glucokinase, glucose homeostasis, and diabetes mellitus. Curr Diab Rep. 2005;5:171-6.

19. Hattersley AT, Pearson ER. Minireview: pharmacogenetics and beyond: the interaction of therapeutic response, beta-cell physiology, and genetics in diabetes. Endocrinology. 2006;147(6):2657-63.

20. Martin D, Bellanné-Chantelot C, Deschamps I, Froguel P, Robert JJ, Velho G. Long-term follow-up of oral glucose tolerance testderived glucose tolerance and insulin secretion and insulin sensitivity indexes in subjects with glucokinase mutations (MODY2). Diabetes Care. 2008;31(7):1321-3.

21. Naylor R, Philipson LH. Who should have genetic testing for maturity-onset diabetes of the young? Clin Endocrinol (Oxf). 2011;75(4):422-6.

22. Lorini R, Klersy C, D’Annunzio G, Massa O, Minuto N, lafusco D, et al. Maturity-onset diabetes of the young in children with inci- dental hyperglycemia : a multicenter Italian study of 172 families. Diabetes Care. 2009;32(10):1864-6.

23. Stride A, Vaxillaire M, Tuomi T, Barbetti F, Njølstad PR, Hansen T, et al. The genetic abnormality in the beta cell determines the response to an oral glucose load. Diabetologia. 2002;45(3):427-35.

24. Ellard S, Bellanné-Chantelot $C$, Hattersley AT. Best practice guidelines for the molecular genetic diagnosis of maturity-onset diabetes of the young. Diabetologia. 2008;51(4):546-53.

25. Murphy R, Ellard S, Hattersley AT. Clinical implications of a molecular genetic classification of monogenic beta-cell diabetes. Nat Clin Pract Endocrinol Metab. 2008;4(4):200-13.

26. García-Herrero C, Rubio-Cabezas O, Azriel S, Navas M. Functional characterization of MODY2 mutations highlights the importance of the fine-tuning of glucokinase and its role in glucose sensing. PLoS One. 2012;7(1e30518):1-9.

27. Yorifuji T, Fujimaru R, Hosokawa Y, Tamagawa N, Shiozaki M, Aizu $\mathrm{K}$, et al. Comprehensive molecular analysis of Japanese patients with pediatric-onset MODY-type diabetes mellitus. Pediatr Diabetes. 2012;13(1):26-32.

28. Sagen JV, Bjørkhaug L, Molnes J, Raeder H, Grevle L, Søvik O, et al. Diagnostic screening of MODY2/GCK mutations in the Norwegian MODY Registry. Pediatr Diabetes. 2008;9(5):442-9.

29. Hwang JS, Shin CH, Yang SW, Jung SY, Huh N. Genetic and clinical characteristics of Korean maturity-onset diabetes of the young (MODY) patients. Diabetes Res Clin Pract. 2006;74(1):75-81.

30. Guazzini B, Gaffi D, Mainieri D, Multari G, Cordera R, Bertolini S, et al. Three novel missense mutations in the glucokinase gene (G80S; E221K; G227C) in Italian subjects with maturity-onset diabetes of the young (MODY). Hum Mutat. 1998;12(2):136. 